\title{
NOTES
}

Smart Home Technology for the Elderly and the Need for Regulation

\section{Jessica Cocco*}

The American population is constantly evolving. Not only has the overall population grown, but the demographics of the American people have changed. One particular demographic has grown considerably over the years - the elderly population. When the United States was founded, the average life expectancy for an American was thirty-five years. ${ }^{1}$ By 1900, this number had increased to 47.3, and in 2000, the average American could expect to see the age of seventy-seven. ${ }^{2}$ Legal professionals must be in tune to these changes. Laws, public policies, and interactions with clients and business associates are all affected by the changing face of America and particularly by the aging face of America.

In this note, I will address particular problems faced by aging Americans, including their desire to live at home as they age, the technological response to this desire, and resultant privacy implications. Section I will discuss the aging of America and the effects of aging on individuals. It will also address the concept of "aging in place," or elderly persons' desire to live independently in their home as they age. Section II will

\footnotetext{
* Jessica Cocco is the Senior Topics Editor of the Pittsburgh Journal of Environmental and Public Health Law. She will receive her J.D. from the University of Pittsburgh School of Law in May 2012. She received her B.A. from the State University of New York at Geneseo. Jessica would like to thank Lawrence A. Frolik, a Professor at the University of Pittsburgh School of Law, for inspiring this note. The author hopes that her work will prove both interesting and informative.
}

${ }^{1}$ U.S. Society: Census and Demographics, U.S. DiPlomatiC Mission to GERMAnY, http://usa.usembassy.de/society-demographics.htm (last updated Oct. 2010).

${ }^{2} I d$. 
Volume 6 Issue 1

Winter 2011

address a form of assistive technology that has recently been developed to counteract the effects of aging and help elderly persons live safely as they age in place. Section III will provide an analysis of the current available privacy protections that could potentially protect the kind of information accumulated and transmitted by smart home technology. It also will address how the Health Insurance Portability and Accountability Act ("HIPAA") and the Fourth Amendment fall short of protecting such information. Section IV will then go on to further discuss the need for regulation and how appropriate regulation is possible.

\section{The Aging OF AMERICA}

From 1900 to 1994, while the total population of the United States tripled, the elderly population (those persons age sixty-five and older) increased by a factor of eleven, rising from about three million to approximately thirty-three million. ${ }^{3}$ In 2006, thirty-seven million Americans, more than twelve percent of the population, were elderly. ${ }^{4}$ The Baby Boomer Generation, born between 1945 and 1964, currently consists of approximately seventy-seven million people, and the oldest members of this generation turned sixty-five in $2010 .^{5}$

By 2030, the elderly population is expected to grow to 71.5 million, almost doubling in size since 2000 and representing about twenty percent of the total population. ${ }^{6}$ This means that approximately one in five Americans will be over the age of sixty-five. ${ }^{7}$ Currently, Americans who reach the age of

${ }^{3}$ Frank B. Hobbs, Population Profile of the United States: The Elderly Population, U.S. CENSUS BUREAU, http://www.census.gov/population/www/pop-profile/elderpop .html (last visited Nov. 10, 2011).

${ }^{4}$ Federal Interagency Forum on Aging-Related Statistics, Older American 2008: Key Indicators of Well-Being, 2 (2008), available at http://www.agingstats.gov/Aging statsdotnet/Main_Site/Data/2008_Documents/Population.pdf.

${ }^{5}$ Ellen Hirsch de Haan, Essay: Housing Trends for the 21st Century, 5 MARQ. ELDER'S ADVISOR 201, 205 (2004), available at http://www.becker-poliakoff.com/ pubs/articles/dehaan_e/dehaan_housing_trends.pdf.

${ }^{6}$ Fed. Interagency Forum, supra note 4.

${ }^{7}$ Hobbs, supra note 3. 
sixty-five have an average life expectancy of an additional 17.9-19.2 years for females and 16.3 years for males.

In the coming years, the resources necessary for the care of the elderly will continue to increase with the growing population. This will not only place a greater responsibility on health-care providers, but on legal professionals as well. As legal professionals advise elderly clients, create and enforce health care regulations, and protect the rights of elderly individuals, the elderly population will increasingly affect the legal profession. Attorneys must prepare for these changing demographics and be able to surmount the challenges presented by them.

\section{A. EFfects of Aging}

The elderly population presents a unique challenge to legal professionals due to the vulnerability of many of its members. One out of three people age sixty-five and older sustains a fall each year. ${ }^{9}$ In 2005 , more than forty-two percent of people age sixty-five and older reported having a functional limitation. ${ }^{10}$ Thirty percent reported difficulty in performing at least one Activity of Daily Living ("ADL") or Instrumental Activity of Daily Living ("IADL"). ${ }^{11}$ Some natural results of aging include: diminished sensory acuity (touch, taste, smell, sight, hearing and temperature); decreased mobility, stamina, and muscle strength; altered stability; as well as altered mental

\footnotetext{
${ }^{8}$ Fact Sheet on Aging in America, EXPERIENCE CORPS, 1 (2007), http://www .experiencecorps.org/images/pdf/Fact\%20Sheet.pdf.

${ }^{9}$ Penny Cheek et al., Aging Well with Smart Technology, 29(4) Nursing Admin. Q. 329, 329 (2005).

${ }^{10}$ William N. Myhill \& Peter Blanck, Disability and Aging: Historical and Contemporary Challenges, 11 MARQ. ELDER'S ADVISOR 47, 56-57 (2009).

${ }^{11}$ Id. ADLs are tasks of everyday life, such as: eating, dressing, getting into or out of a bed or chair, taking a bath or shower, and using the toilet. Dictionary of Cancer Terms, NATIONAL CANCER INSTITUTE, available at http://www.cancer.gov/dictionary? cdrid=430402. An IADL is an activity related to independent living, such as: preparing meals, managing money, shopping, doing housework, and using a telephone. Id.
} 


\section{Volume 6 Issue 1}

Winter 2011

clarity. ${ }^{12}$ As people age, there is also an increased likelihood of osteoporosis, arthritis, heart disease, hypertension, and diabetes. ${ }^{13}$

Recent estimates predict that somewhere between 2.4 million and 5.1 million Americans suffer from Alzheimer's disease. ${ }^{14}$ Studies indicate that forty-two percent of elderly people age eighty-five and older have some form of dementia. ${ }^{15}$ Many elderly persons also experience the loss of spouse and close friends, which can lead to social isolation and an increased need for safety measures. ${ }^{16}$ The elderly typically depend on support from their families and social service systems and may have substantially less control over the decisions affecting their lives than they previously had. ${ }^{17}$ The elderly, particularly those who suffer from Alzheimer's or another form of dementia, "defy the conventional view of rights as implying fully rational, autonomous individuals who can exercise free choice and require freedom from governmental interference," posing a particular problem for legal professionals. $^{18}$

\footnotetext{
${ }^{12}$ Cheek et al., supra note 9, at 329-30.

${ }^{13}$ Aging in Place, SENIORRESOURCE.COM, http://www.seniorresource.com/ageinpl .htm (last visited Nov. 10, 2011).

${ }^{14}$ Alzheimer's Information: General Information, NAT'L INST. ON AGING, http://www .nia.nih.gov/Alzheimers/AlzheimersInformation/GeneralInfo/ (last updated Dec. 8, 2010).

${ }^{15}$ Allison Marie Kenner, Securing the Elderly Body: Dementia, Surveillance, and the Politics of "Aging in Place," 5(3) SurveILlance \& SOC'Y 252, 254 (2008), available at http://www.surveillance-and-society.org/articles5(3)/elderly.pdf.

${ }^{16}$ Cheek et al., supra note 9 , at 330.

${ }^{17}$ Kenner, supra note 15.

${ }^{18}$ Karen Eltis, Predicating Dignity on Autonomy? The Need for Further Inquiry into the Ethics of Tagging and Tracking Dementia Patients with GPS Technology, 13 Elder L.J. 387, 389-90 (2005) (citing Tamar Ezer, A Positive Right to Protection for Children, 7 Yale Hum. RTS. \& DeV. L.J. 1, 2 (2004)).
} 


\section{B. Aging in Place}

Even though elderly persons and their families are aware of the risks, more and more of the elderly population chooses to live independently and privately. ${ }^{19}$ Almost ninety-two percent of older Americans live alone in apartments, houses, or in independent living and assisted living facilities. ${ }^{20}$ This includes half of those persons age seventy-five and older. ${ }^{21}$ Such numbers reflect the fact that as people age, many prefer to do so at home, a concept known as "aging in place." Aging in place has been defined as "living where you have lived for many years, or living in a non-health care environment, using products, services and conveniences to allow or enable you to not have to move as circumstances change." 22 Studies show that seventy to eighty percent of older Americans prefer to age in place. ${ }^{23}$

As a result, approximately seventy percent of elderly persons spend the rest of their lives in the same place they celebrated their sixty-fifth birthday. ${ }^{24}$ There are numerous reasons why there is such a strong preference among the elderly to age in place. Many prefer to do so because it provides familiarity, a comfortable environment, and security while allowing them to retain a sense of independence. ${ }^{25}$

${ }^{19}$ Janine Rankin, Smart Monitor for Elderly, MANAWATU STANDARD (N.Z.), July 8, 2008, at 5, available at http://www.stuff.co.nz/manawatu-standard/news/523821/ Smart-monitor-for-elderly.

${ }^{20}$ Myhill \& Blanck, supra note 10 , at 58.

${ }^{21} I d$.

${ }^{22}$ Aging in Place, supra note 13.

${ }^{23}$ Robin Benedick, Tapping Technology for Elder Care, S. FLORIDA SUN-SENTINEL, Sept. 19, 2004, at 13 ("'Study after study we do tells us that 70 to 80 percent of the people want to stay where they are as they get older,' said Elinor Ginzler, manager of independent living and long-term care for the AARP in Washington, D.C.").

${ }^{24}$ Aging in Place, supra note 13.

${ }^{25} I d$. 


\section{Volume 6 Issue 1}

Winter 2011

\section{The Dangers of Aging in Place}

However, aging in place can be dangerous because as previously stated, one third of all elderly persons fall each year. ${ }^{26}$ Studies from hospital admissions show that falls in the home are the dominant cause of injury among the elderly. ${ }^{27}$ Such falls typically occur because the environment is not suited for the needs of elderly individuals. ${ }^{28}$ The next two largest causes of home injuries among the elderly are burns and medicine-related poisoning. ${ }^{29}$ Burns are primarily caused by fires. ${ }^{30}$ The elderly are "killed in home fires at twice the rate of society as a whole." ${ }^{31}$ This is most likely due to elderly persons forgetting to turn the stove off or leaving candles burning. The main cause of poisoning is medicine non-compliance, because the elderly are six times more likely to suffer adverse medical reactions than other age groups. ${ }^{32}$ Therefore, in order to allow an elderly person to safely age in place, certain measures must be taken to accommodate the mental, physical, and psychological decline that will likely occur.

\section{The Attempt to Alleviate Some of The Dangers of Aging in Place}

There is a delicate balance between ensuring the safety and security of elderly individuals and allowing them to maintain a sense of autonomy. In recent years, many technologies have been developed in an attempt to preserve that balance. Supportive services now exist to attempt to preserve one's sense of independence while providing a safe environment. Some

\footnotetext{
${ }^{26}$ Cheek et al., supra note 9, at 332.

${ }^{27}$ Henrik Eriksson \& Toomas Timpka, The Potential of Smart Homes for Injury Prevention among the Elderly, 9(2) Inj. Control \& SAFETy Promotion 127, 127 (2002).

${ }^{28}$ Aging in Place, supra note 13.

${ }^{29} I d$.

${ }^{30} I d$.

${ }^{31} I d$.

${ }^{32} I d$.
} 
examples of assistive technology ("AT") used among older Americans include: devices which provide "compensatory services for cognitive, sensory, and physical disabilities"; modifications to the design, lighting, and furnishing of environments; sensors and network systems that monitor health, trigger response services or perform domestic tasks; and various methods of social communication. ${ }^{33}$ The focus of this article will be on the development of a specific type of AT, "smart home technology," and its implications on privacy and the need for regulation.

\section{SMART Home TeChNOLOGY}

\section{A. What IS "SMART HoMe TECHNOLOGY"?}

As used for the elderly, smart home technologies are "information-based technologies that passively collect and share resident information with the resident and family members in addition to primary care providers. ${ }^{134}$ Smart home technology can also be defined as "using basic and assistive devices to build an environment in which many features in the home are automated and where devices can communicate with each other." ${ }^{35}$ Smart home devices collect physiological, locational, and movement data, which can then be used for early detection and intervention by health care providers, residents, and their families. ${ }^{36}$

\footnotetext{
${ }^{33}$ Myhill \& Blanck, supra note 10, at 68.

${ }^{34}$ Karen L. Courtney et al., Needing Smart Home Technologies: The Perspectives of Older Adults in Continuing Care Retirement Communities, 16 INFORMATICS PRIMARY CARE 195, 196 (2008).

${ }^{35}$ Cheek et al., supra note 9 , at 330.

${ }^{36}$ Courtney et al., supra note 34 .
} 
Volume 6 Issue 1

Winter 2011

\section{B. TYPES OF TECHNOLOGIES}

There are a number of different kinds of devices that can be used to monitor elderly residents. The two basic categories that the technologies fall into are active-intervention devices and passive-intervention devices. ${ }^{37}$

\section{Passive Intervention DeVices}

Passive-intervention devices monitor a patient's condition and safety without intervening in his or her care. ${ }^{38}$ An example of such a device is one that can slip under mattress pads to detect heart rate, respiration, and restlessness. ${ }^{39}$ Others detect motion within the home. These sensors can provide data regarding the resident's location over time, such as the number of bathroom visits, or can be used with other sensors to develop rich activity patterns. ${ }^{40}$ If a smart home occupant spends an unusually long amount of time in the bathroom, and a sensor has detected no motion, it can then notify a caregiver. ${ }^{41}$ Sensors can monitor behavior ranging from how well someone is sleeping to whether he or she is still capable of washing dishes. ${ }^{42}$ Because of this technology, family members or caregivers know if someone has uncharacteristically missed his or her favorite TV show or failed to eat breakfast. ${ }^{43}$ Humidity sensors check whether homeowners are regularly using the sink or shower. ${ }^{44}$ Gait monitors in the floor can detect changes in a

${ }^{37}$ Melissa Sanchez, Technology Can Help Improve Home Safety, FORT WORTH STARTELEGRAM, June 4, 2006, at BB.

${ }^{38} I d$.

${ }^{39}$ Courtney et al., supra note 34.

${ }^{40} I d$.

${ }^{41}$ Benedick, supra note 23.

${ }^{42}$ Marilyn Rauber, High-Tech Sensors' Benefits Numerous: 'Smart' House Devices May Help Elderly Stay Home, RichmOND Times DisPatch, Apr. 27, 2003, at J1.

${ }^{43}$ Jack Cox, Telemedicine Monitors the Elderly from Afar, New ORLEANS Times PICAYUNE, Aug. 19, 2004, at 2.

${ }^{44}$ Rauber, supra note 42.

P a g e $\mid 92$ 
person's ability to walk as well as detect falls. ${ }^{45}$ These passive intervention devices can indicate a decline in a resident's health or detect problems as they arise. This record of the resident's health allows family members and caregivers to act and take preventive measures, as opposed to remedial ones after an incident occurs.

\section{ACTIVE-INTERVENTION DEVICES}

Active-intervention devices take a more active role in patient care. As with passive devices, there are various types of active devices. These types of technologies include sensors equipped with alerts, reminder systems, and devices that assist with medication administration.

\section{a. SENSORS}

Active-intervention sensors passively monitor residents and may interfere on the resident's behalf if necessary. ${ }^{46}$ Some active-interventions sensors monitor vital signs while others use silhouette video images to detect if a person has fallen and is unable to get up. ${ }^{47}$ The system then alerts primary care physicians and family members so the resident does not have to activate the system to report a fall or summon help. ${ }^{48}$ Smart clothes are equipped with sensors that monitor behavior and physiological conditions. ${ }^{49}$ Smart shirts can detect vital signs, upload electrocardiogram results, and measure blood flow. ${ }^{50}$ This information can then be transmitted to a physician for diagnosis and treatment. ${ }^{51}$

${ }^{45} I d$.

${ }^{46}$ Sanchez, supra note 37.

${ }^{47}$ Courtney et al., supra note 34.

${ }^{48} I d$.

${ }^{49}$ Eriksson \& Timpka, supra note 27, at 128.

${ }^{50}$ Cheek et al., supra note 9.

${ }^{51} \mathrm{Id}$. 
Volume 6 Issue 1

Winter 2011

\section{b. REMINDER SYSTEMS}

Other devices serve as reminder systems for elderly users. Some systems have automotive enunciators that tell residents information such as the date, time, what tasks must be performed, and upcoming appointments and events. ${ }^{52}$ Other devices are designed to alert residents if a stove burner is turned on and left unattended for a set amount of time. ${ }^{53}$ Many of these reminder systems perform the task if the resident does not respond so to ensure resident safety. ${ }^{54}$ Some examples of the tasks that are performed for the resident are turning the stove off, stopping the running of bath water, and locking doors. ${ }^{55}$

\section{Medication Assistance}

There are numerous devices that assist in medication administration. Such technologies include: automated pill dispensers; sensor pads located underneath medication bottles to detect when and if medications are taken; and prototype robots that track owners to give them their pills. ${ }^{56}$ There are also "virtual pets" that owners feed and care for by pushing buttons. ${ }^{57}$ Owners must push the buttons only to report when they take their medication, and if they do not comply with their medication regimen, the pet gets sick. ${ }^{58}$ Some smart home technologies remind occupants to take medicine as well as scan the prescription bottle to make sure that it is the correct one. ${ }^{59}$ The technology

${ }^{52} I d$. at 332 .

${ }^{53}$ Courtney et al., supra note 34.

${ }^{54}$ Cheek et al., supra note 9, at 333.

${ }^{55} \mathrm{Id}$.

${ }^{56} I d$.

${ }^{57} \mathrm{Id}$.

${ }^{58} \mathrm{Id}$.

${ }^{59}$ Benedick, supra note 23. 
also keeps an inventory of pills and can call a pharmacy to order prescriptions when running low. ${ }^{60}$

\section{Benefits of Smart Home Technology}

The use of smart home technology has an array of benefits, including reducing the number of adverse incidents, as well as providing support and intervention for conditions such as chronic illness, falls, dementia, medication problems, wandering, and social isolation. ${ }^{61}$ Smart home technologies can assist with aging in place by facilitating performance of ADLs and IADLs, providing safety and monitoring, and compensating for an individual's functional limitations. ${ }^{62}$ Studies have shown that using smart home technology can reduce hospital admissions and decrease the length of stay if admitted. ${ }^{63}$

According to a report by the Australian Academy of Technological Sciences and Engineering, a ten percent reduction in the number of accidental falls would save the Australian health care system about $\$ 85$ million a year. ${ }^{64}$ The same report found that the application of smart home technology could not only offer savings in the public and private sector, but also improve the quality of life of the elderly by minimizing falls and accidents in the home thanks to the early warnings of changes in health. ${ }^{65}$ Essentially, smart home

${ }^{60} I d$.

${ }^{61}$ Jeffrey Soar, Reinventing Health; Ageing and Aged Care Through Smart Homes and Intelligent Technologies, FOURTH INTERNATIONAL CONFERENCE ON COOPERATION AND PROMOtion of Information Resources in SCIENCE AND TECHNOLOGY, 73 (2009).

${ }^{62}$ Myhill \& Blanck, supra note 3, at 68.

${ }^{63}$ Cheek et al., supra note 9, at 335.

${ }^{64}$ Karen Dearne, Technology the Ticket to Elderly Home Care, Australian, July 14, 2010 , at 12 .

${ }^{65}$ Greg Thom, Hi-tech Homes for Seniors, HeRALD Sun (Australia), July 26, 2010, at 18.

P a g e $\mid 95$ 
Volume 6 Issue 1

Winter 2011

technologies enhance a user's quality of life and reduce health care costs through injury and disease prevention and early intervention. ${ }^{66}$

Because of the aforementioned assistance, monitoring, emergency and preventive measures that smart technologies provide, people are able to realize the goal of aging in place. The main advantage to smart home technology is that it allows the elderly to stay in a familiar and comfortable environment and delays or avoids admittance to a nursing home. ${ }^{67}$ Patients can remain autonomous but be continuously monitored, empowering patients by making them feel more informed and actively involved in their care. ${ }^{68}$ Furthermore, smart home technology can reduce social isolation due to the sense of security from having someone monitoring one's status. ${ }^{69}$

\section{CONCERnS With SMART Home Technology}

Despite all the possible benefits, there are critics who raise serious concerns about smart home technology. Some worry that this kind of remote surveillance may lead to even more disconnect from society. ${ }^{70}$ "In trying to promote autonomy, we may end up promoting isolation. In keeping people in their homes past the point where they can interact with the community, we've essentially put them under house arrest. ${ }^{71}$ Some of the concerns that must be addressed before utilizing smart home technology include: tailoring systems to meet the needs of individual patients; making systems user friendly; and minimizing the costs of retrofitting existing homes to accommodate the technology. ${ }^{72}$ People's willingness to use this kind of technology is another

\footnotetext{
${ }^{66}$ Courtney et al., supra note 34, at 197.

${ }^{67}$ Cheek et al., supra note 9 , at 335.

${ }^{68} I d$.

${ }^{69} I d$.

${ }^{70}$ Cox, supra note 43 , at 2.

${ }^{71} I d$. at 1 .

${ }^{72}$ Cheek et al., supra note 9, at 329, 335-36.
} 
hurdle. An individual's self-perception of need is a critical factor in determining his or her readiness to use the technology. ${ }^{73}$

Another determinative factor is the invasiveness of the technology. The more intrusive the technology, the less willing people are to use it. ${ }^{74}$ Researchers at the University of Virginia found that many of the older people interviewed in focus groups were very suspicious of video cameras. ${ }^{75}$ Additional concerns with so much remote monitoring include a fear of lack of human responders and the replacement of caregivers by technology. ${ }^{76}$

While such concerns are important, the focus of this paper is the legal and ethical concerns that surround these technologies. Smart home technology has an immense potential to restrict the most basic rights of the elderly, notably the rights to liberty, privacy, equality, and dignity. The types of monitors and sensors used in smart homes can give people access to the most intimate details of a person's life. Such "advances in information technology ... have eroded the effectiveness of existing constitutional and statutory protections. ${ }^{77}$

\section{Privacy Protection In the United States}

As the Supreme Court stated in Union Pac. R.R. v. Botsford, "no right is held more sacred, or is more carefully guarded ... than the right of every individual to the possession and control of his own person, free from restraint or interference of others, unless by clear and unquestionable authority." ${ }^{78} \mathrm{In}$ some regards, smart homes advance this notion by allowing elderly individuals to live in their homes and retain their autonomy. But this autonomy comes at a cost. To ensure the safety of elderly individuals, family

\footnotetext{
${ }^{73}$ Courtney et al., supra note 34, at 198.

${ }^{74}$ Id. at 199.

${ }^{75}$ Rauber, supra note 42.

${ }^{76}$ Cheek et al., supra note 9, at 336.

${ }^{77}$ Charles Weiss, The Coming Technology of Knowledge Discovery: A Final Blow to Privacy Protection, 2004 U. ILL. J.L. TECH. \& POL'Y 253, 256 (2004).

${ }^{78}$ Union Pac. R.R. v. Botsford, 141 U.S. 250, 251 (1891).
} 
Volume 6 Issue 1

Winter 2011

members and care-givers may take intrusive measures. The limitations imposed on civil liberties of the elderly are often taken for granted "as a presumed natural consequence of their degenerating health and our wellintentioned, yet paternalistic, desire to ensure their medical well-being." ${ }^{79}$ Although this invasive technology can help protect elderly individuals, a critical eye reveals a myriad of legal issues and rights infringement.

\section{A. The General Right to Privacy}

In 1890, Samuel Warren and Louis Brandeis addressed the fact that "recent inventions ... call attention to the next step which must be taken for the protection of the person, and for securing to the individual . . . the right 'to be let alone."'"80 They explained that the general object of a right to privacy "is to protect the privacy of private life." ${ }^{81}$ Faced with technological advancements such as instantaneous photographs and the newspaper enterprise, Warren and Brandeis examined whether the existing law "afforded a principle which can properly be invoked to protect the privacy of the individual; and if it does, what the nature and extent of such protection is." ${ }^{12}$

Ten state constitutions expressly grant a right to privacy. ${ }^{83}$ The concept of privacy "encompasses ideas of bodily and social autonomy, of selfdetermination, and of the ability to create zones of intimacy and inclusion that define and shape our relationships with others." ${ }^{84}$ In Griswold v. Connecticut, the Supreme Court stated that the "specific guarantees in the Bill of Rights have penumbras, formed by emanations from those guarantees that help give

\footnotetext{
${ }^{79}$ Eltis, supra note 18, at 390.

${ }^{80}$ Samuel D. Warren \& Louis D. Brandeis, The Right to Privacy, 4 HARV. L. REV. 193, 195 (1890).

${ }^{81} I d$. at 215.

${ }^{82}$ Id. at 197.

${ }^{83}$ Alaska COnST. art. I, $\S 22$; ARIz. Const. art. II $\S 8$; CAL. COnST. art. I $\S 1$; Fla. CONST. art. I $\S \S 12,23$; HAw. Const. art. I $\S \S 6-7$; ILL. Const. art. I $\S \S 6,12$; LA. Const. art. I $\S 5$; MONT. CONST. art. II $\S 10$; S.C. Const. art. I $\S 10$; WASH. Const. art. I $\S 7$.

${ }^{84}$ A. Michael Froomkin, The Death of Privacy?, 52 STAN. L. REV. 1461, 1466 (2000).
}

\section{P a g e $\mid 98$}


them life and substance. ${ }^{185}$ The Court went on to explain that the penumbras of the First, Third, Fourth, Fifth and Ninth Amendments "create zones of privacy." ${ }^{\prime 86}$

Thus, while the United States Constitution does not explicitly recognize a right to privacy, there are zones of privacy that are protected. Additionally, Warren and Brandeis's concern over one hundred years ago illustrates that even if it is not explicitly protected, the right to privacy is one that has been long valued by Americans.

\section{B. Fourth Amendment Privacy}

"The pre-eminent guarantee of personal privacy. . . in the United States is the Fourth Amendment." ${ }^{87}$ This prohibition against unreasonable searches and seizures is founded in the maxim that "every man's house is his castle." ${ }^{88}$ Yet this protection is not as all encompassing as it seems.

\section{INFORMATION CONVEYED TO A THIRD PARTY IS NOT PRoteCTED}

Modern Fourth Amendment jurisprudence holds that communications and activities are only private to the extent that a person shields them from observation by others. ${ }^{89}$ In Smith v. Maryland, the Supreme Court ruled that there was no "expectation of privacy" in numbers dialed from a telephone. ${ }^{90}$ Because that information was "voluntarily conveyed" to a third party, the

\footnotetext{
${ }^{85}$ Griswold v. Connecticut, 381 U.S. 479, 484 (1965).

${ }^{86} \mathrm{Id}$.

${ }^{87}$ Susan W. Brenner, The Fourth Amendment in an Era of Ubiquitous Technology, 75 Miss. L.J. 1, 1 (2005).

${ }^{88}$ Id. at 4 .

${ }^{89}$ Id. at 50 .

${ }^{90}$ Smith v. Maryland, 442 U.S. 735, $743-44$ (1979).
} 
Volume 6 Issue 1

Winter 2011

telephone company, that information was "exposed," and Smith "assumed the risk that the company would reveal to the police the numbers he dialed." ${ }^{11}$

The Court further explained this rationale in United States v. Jacobsen where the question before it was whether law enforcement officials viewing evidence that private parties had brought to their attention constituted a "search" under the Fourth Amendment. In response, the Court stated:

when an individual reveals private information to another, he assumes the risk that his confidant will reveal that information to the authorities, and if that occurs, the Fourth Amendment does not prohibit governmental use of that information .... The Fourth Amendment is only implicated if the authorities use information with respect to which the expectation of privacy has not already been frustrated. ${ }^{92}$

Such a stance could have serious repercussions for those elderly persons who choose to live in a smart home if proper regulations are not in place. Under this rationale, one could argue that the information collected by the technologies and transmitted to others is not protected and could be free for search by the government-turning smart homes into technologically advanced fishbowls.

\section{UNDER CURRENT FOURTH AMENDMENT JURISPRUDENCE, INFORMATION FROM SMART HOMES Would Not Be Protected}

In drafting the Fourth Amendment, the founding fathers were concerned with a physical intrusion into one's home, but had they conceived of technology that allowed the government remote access to the interior of person's home, they would most likely have found it just as reprehensible. On

\footnotetext{
${ }^{91} I d$.
}

${ }^{92}$ United States v. Jacobsen, 466 U.S. 109, 117 (1984) (holding that because the private parties' observation of the material had already frustrated Jacobsen's privacy interest in it, the subsequent observance by law enforcement did not constitute a "search" under the Fourth Amendment), id. at 118-19. 
this point, the Supreme Court has agreed. In Kyllo v. United States the Court held that where "the Government uses a device that is not in general public use, to explore details of the home that would previously have been unknowable without physical intrusion, the surveillance is a 'search' and is presumptively unreasonable without a warrant." ${ }^{93}$

While this precedent provides strong support for the privacy that is expected in one's home, it does not protect smart home technology. In Kyllo, the government was using the technology to "explore details of the home" without the knowledge or consent of the people inside. ${ }^{94}$ With smart home technology, however, the resident is fully aware of the technology and the information it collects, as well as the transmission of that information to a third party. Because government officials could retrieve the information once it passed to a third party instead of performing the actual surveillance itself, the cases would be governed by the precedents of Smith and Jacobsen, not Kyllo. But governing smart home technology through the lens of Smith and Jacobsen thwarts the intention of the Fourth Amendment and Americans' deep-rooted belief in personal privacy.

In Boyd v. United States, the Supreme Court described the Fourth and Fifth Amendments as protections against all governmental invasions into "the sanctity of a man's home and the privacies of his life." ${ }^{95}$ The Court went on to explain that "it is not the breaking of doors, and the rummaging of his drawers, that constitutes the essence of the offense; but it is the invasion of his indefeasible right of personal security, personal liberty and private

\footnotetext{
${ }^{93}$ Kyllo v. United States, 533 U.S. 27, 40 (2001) (questioning whether the use of a thermal-imaging device aimed at a private home from a public street in order to detect relative amounts of heat within the home constituted a "search" within the meaning of the Fourth Amendment), id. at 29.

${ }^{94} I d$. at 30 ("The scan of Kyllo's home took only a few minutes and was performed from the passenger seat of Agent Elliott's vehicle across the street from the front of the house and also from the street in back of the house.").

${ }^{95}$ Boyd v. United States, 116 U.S. 616, 630 (1886).
} 


\section{Volume 6 Issue 1}

Winter 2011

property ... which underlies and constitutes the essence of [this] judgment." 96

\section{The HIPAA Privacy RULe}

HIPAA is the preeminent privacy protection for health information. It was enacted in $1996 .{ }^{97}$ HIPAA required the Secretary of Health and Human Services to issue privacy regulations governing individually identifiable health information if Congress did not enact privacy legislation within three years. ${ }^{98}$ Because Congress did not do so, the Department of Health and Human Services published the final regulation: the Standards for Privacy of Individually Identifiable Health Information ("Privacy Rule") on December 28, 2000. ${ }^{99}$ The Privacy Rule established national standards for the protection of certain health information. ${ }^{100}$

The Privacy Rule applies to any "covered entity," which is "a health plan," "a health care clearinghouse," or "a health care provider who transmits any information in electronic form in connection with a transaction covered by this subchapter." 101 As defined by the regulation, health plans are individual and group plans that provide or pay the cost of medical care. ${ }^{102}$ Health care clearinghouses are entities that process nonstandard health information that they receive from another entity into a standard or vice

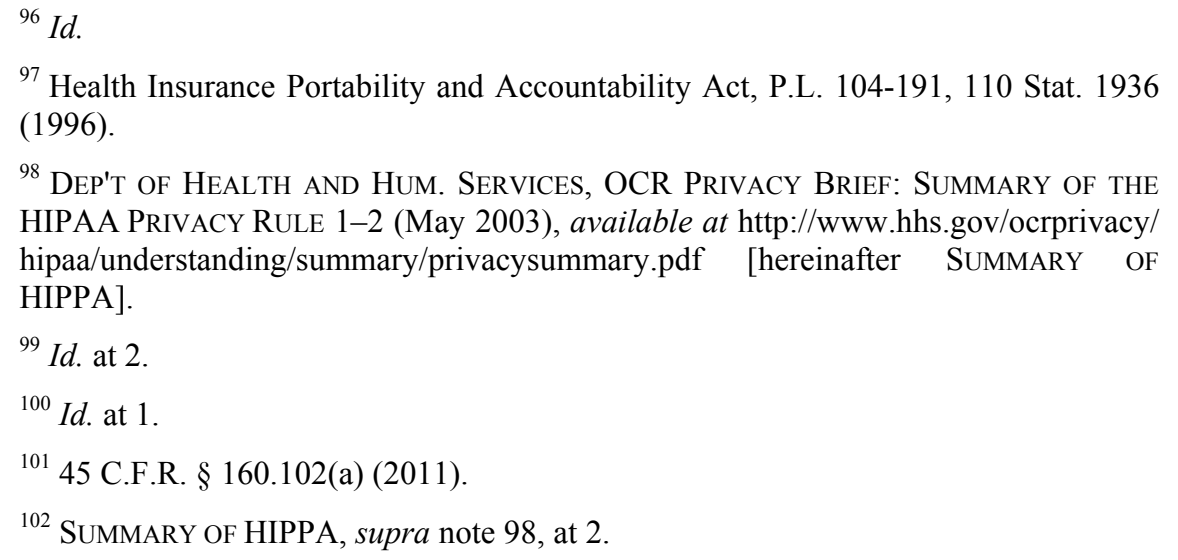


versa. ${ }^{103}$ Health care provider refers to every health care provider, regardless of size, which electronically transmits health information in connection with transactions such as: claims; benefit eligibility inquiries; referral authorization requests; or other transactions for which Health and Human Services has established standards under the HIPAA Transactions Rule. ${ }^{104}$

The Privacy Rule prohibits a covered entity from using or disclosing protected health information except as permitted or required by the rule. ${ }^{105} \mathrm{~A}$ covered entity is permitted to disclose information to: the individual; for treatment, payment or health care operations; incident to another permitted or required disclosure; pursuant to a valid authorization; and pursuant to an agreement. ${ }^{106} \mathrm{~A}$ covered entity is required to disclose protected health information to an individual when requested, and to the Secretary to investigate or determine the covered entity's compliance with the Privacy Rule. $^{107}$

\section{The Existing Regulations Are not Enough to Protect SMART HoMe RESIDENTS}

On its face, HIPAA appears to provide vast protection against the disclosure, use, and abuse of health information. However, it falls short of providing adequate protection for those elderly persons who live or will live in smart homes. Its shortcomings are twofold. First, the definition of protected health information does not cover the vast range of information that is collected and transmitted by smart home technology. Secondly, the covered entities that must abide by the restrictions of the Privacy Rule do not include potential recipients of the information sent from the smart home technology.

\footnotetext{
${ }^{103} I d$. at 3.

${ }^{104} \mathrm{Id}$. at 2.

${ }^{105} 45$ C.F.R. § 164.502(a) (2011).

${ }^{106} 45$ C.F.R. $\S 164.502(a)(1)$ (2011).

${ }^{107} 45$ C.F.R. § 164.502(a)(2) (2011).
} 
Volume 6 Issue 1

Winter 2011

\section{a. "PROTECTED HEALTH INFORMATION" AND SMART HOME TECHNOLOGY}

As defined by the Privacy Rule, "protected health information" means individually identifiable health information that is: "transmitted by electronic media; maintained in electronic media; or transmitted or maintained in any other form or medium." ${ }^{108}$ While the information gathered by smart home technology would clearly be covered by the latter part of the definition, the problem lies in the definition of "individually identifiable health information."

Individually identifiable health information is health information that is created or received by a covered entity and "relates to the past, present, or future physical or mental health or condition of an individual; the provision of health care to an individual; or the past, present, or future payment for the provision of health care." 109 The information must also identify either the individual or there must be "a reasonable basis to believe the information can be used to identify the individual."

The kinds of information collected and transmitted by smart home technology go beyond the scope of the definition. While the information pertaining to a resident's heart rate, respiration, and medication intake will most likely be protected, information about his or her location in the home over time would most likely not be. To consider information regarding whether someone missed a television show or used the sink "protected health information" would be a stretch of the definition. ${ }^{111}$

\section{COVERED EnTITIES AND SMART HoMe TEChNOLOGY}

As addressed above, the HIPAA Privacy Rule only applies to covered entities, which are health plans, health care clearinghouses, or health care

\footnotetext{
${ }^{108} 45$ C.F.R. $\S 160.103$ (2011).

10945 C.F.R. $\S 160.103$ (2011) (emphasis added).

${ }^{110} \mathrm{Id}$.

${ }^{111}$ See supra notes 43-44 and accompanying text.
} 
providers. ${ }^{12}$ Yet the information acquired by smart home technology is not just shared with a health care provider or the other covered entities. The information is often shared with family members of the individual resident. ${ }^{113}$ In some instances, the information could be sent to a company that has been assigned to monitor the individual. ${ }^{114}$ It is also possible to consider a situation where an elderly person has a friend to whom his or her information is sent. Family members, friends of residents, and companies in charge of monitoring residents do not fit into any of the definitions of the covered entities. Any kind of expansion of the definition to include them would be implausible.

\section{THE NEED fOR ADDitionAl REgUlation-FOURTH AMENDMENT JURISPRUDENCE COMBINED WITH HIPAA'S SHORTCOMINGS COULD LEAD TO GOVERNMENT INTRUSION}

Until proper regulation is in place, smart home information is in protection limbo. Without explicit regulations protecting smart home information, information outside the realm of traditional health information (e.g., heart rate, respiration) will be open to use and possible abuse by third parties, including the government.

As discussed above, Fourth Amendment jurisprudence holds that when a person transmits or allows a third party to observe information, that person has frustrated his or her privacy interest in it. ${ }^{115}$ Therefore, HIPAA's shortcomings will allow the government to view and use transmitted information free from any Fourth Amendment implication.

So, what does this mean for smart home technologies? If elderly persons choose to live in smart homes to ensure their safety and security, do they completely surrender their privacy in the data compiled by the technology? By choosing to live in a smart home, has an elderly person "assumed the risk" that this information could be revealed? Once in the home, the elderly would

\footnotetext{
11245 C.F.R. $\S 160.102(a)$ (2011).

${ }^{113}$ Courtney et al., supra note 34 .

${ }^{114}$ Benedick, supra note 23.

${ }^{115}$ Smith, 442 U.S. at 744; see also, e.g., Jacobsen, 466 U.S. at 117.
} 


\section{Volume 6 Issue 1}

Winter 2011

have no way of shielding the information, just as Smith had no way of shielding the numbers he dialed on his telephone. ${ }^{116}$

But smart home technology poses a far greater intrusion into personal privacy than occurred in Smith. The data at issue with smart homes could concern almost every detail of a person's life, including bathroom visits, interactions with other people, food intake, medications, sleep cycles, and physiological data. Thus, it is necessary to institute proper regulations to reconcile the interest in privacy protection in the home with this kind of pervasive technology.

Surely the solution cannot be that by choosing to live in a smart home, elderly people have completely frustrated their privacy interests in the information taken from the inside of their own homes. The elderly are a particularly vulnerable demographic. They are frailer, more susceptible to injury and illness, and often suffer diminished mental capacity. Such persons require protection and care; yet more and more elderly individuals desire to receive this care at home. By avoiding a nursing home, elderly individuals feel as though they maintain their autonomy and privacy. By making this choice they have completely surrendered the privacy of their home. Such a conclusion would fly in the face of the original intent of the Fourth Amendment and strong social beliefs in a person's right to personal autonomy and privacy in his or her home.

The ... constitutional prohibition against unreasonable searches and seizures, has its source in that principle of the common law which finds expression in the maxim that "every man's house is his castle." English history discloses [that the] ... constitutional provisions ... had their origin "in the ... unwarrantable intrusion of executive agents into the houses ... of individuals." ${ }^{117}$

\footnotetext{
${ }^{116}$ See Smith, 442 U.S. at 745.

${ }^{117}$ Brenner, supra note 87, at 4 (citing United States v. Three Tons of Coal, 28 F. Cas. 149, 151 (E.D. Wis. 1875)).
} 


\section{CONCLUSION}

The simple fix to the problem with the definition of "protected health information" is to say that all information received from a smart home "relates to" the individual's "physical or mental health or condition." Similarly, a solution to the problem of the "covered entities" definition is to state that all the information collected and transmitted by smart home technology is protected, regardless of the appointed recipient of the information. Both of these measures can be accomplished by adding provisions into the existing Privacy Rule. The drafting requires specificity in the definitions of smart homes and smart home technology. It also requires a standard to provide for who would be eligible to qualify as a recipient of an individual resident's information. Careful consideration would be necessary, but proper regulation is possible.

Because the existing protections afforded by HIPAA do not apply to many of the possible problems posed by smart homes, and the applicable Fourth Amendment jurisprudence would lead to a perversion of the right the Fourth Amendment was intended to protect, regulations are necessary to ensure the privacy of smart home residents. With the expected growth of the elderly population due to the aging of the Baby Boomer generation, the health care needs of the elderly will become a national issue in the years to come. Because of the vast benefits that smart home technologies offer to individual residents, as well their potential to reduce and delay hospital and nursing home admittances, they will play an increasingly important role in the health care of the elderly in the coming years.

The rights of the elderly should not be overshadowed by their health concerns. Physical or cognitive impairment does not justify a denial of fundamental rights in the name of safety. As leading researcher Susan Dodds emphasizes, "there is no reason to believe that as people become older and less able to live fully independently, they lose all interests beyond the protection of their health." ${ }^{118}$ Proper regulations are possible and must be put in place to protect the information received and transmitted by smart home

\footnotetext{
${ }^{118}$ Susan Dodds, Exercising Restraint: Autonomy, Welfare and Elderly Patients, $22 \mathrm{~J}$. MED. ETHICS 160, 162 (1996).
} 
Journal of Environmental and Public Health Law
Volume 6 Issue 1

Winter 2011

technology. Only then can elderly persons' safety be ensured, while at the same time, their dignity and autonomy as citizens is secured. 